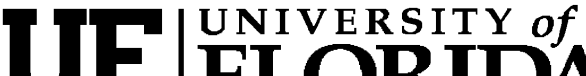 FLORIDA \\ IFAS Extension
}

\section{Licensing of Forest Pesticide Applicators in Florida ${ }^{1}$}

\author{
Frederick M. Fishel $^{2}$
}

This document explains the licensing and regulation of persons who apply pesticides to forest sites in Florida, as regulated by the Florida Pesticide Law (Chapter 487), and administered by the Florida Department of Consumer Services.

\section{Forest Pest Control}

All persons who apply or supervise the application of restricted use pesticides to forest sites must have a pesticide applicator license issued by the Bureau of Compliance Monitoring/Pesticide Certification Section. The Forestry Pest Control category is regulated by the Florida Pesticide Law (Florida Statutes, Chapter 487).

\section{Category Certification Standards}

Applicators seeking a license in this category must demonstrate practical knowledge of:

- The types of forests, forest nurseries, and seed orchards in Florida and associated pests;

- Forest population dynamics;
- Relative biotic agents and vulnerability to pesticides;

- The chemical control measures that pertain to the prevention or control of such pests; and

- The equipment or methodologies required to safely and effectively implement such measures while avoiding adverse effects on wildlife, ground or surface water, and recreational areas visited by the general public.

\section{License classification}

Certified forestry pest control applicators may be licensed as either public applicators or commercial applicators. These are the major differences:

- A public applicator is a licensed applicator employed by a public or governmental agency. The license is only valid when performing work for the public or governmental agency. The public applicator fee for a four-year license is $\$ 60$.

- A commercial applicator is a licensed applicator who is licensed to apply restricted-use pesticides on any property provided they are certified in the

1. This document is PI-130, one of a series of the Pesticide Information Office, Florida Cooperative Extension Service, Institute of Food and Agricultural Sciences, University of Florida. Original publication date July 2006. Visit the EDIS Web Site at http://edis.ifas.ufl.edu.

2. Frederick M. Fishel, associate professor, Agronomy Department, and Director, Pesticide Information Office; Florida Cooperative Extension Service, Institute of Food and Agricultural Sciences, University of Florida, Gainesville, FL 32611.

The use of trade names in this publication is solely for the purpose of providing specific information. UF/IFAS does not guarantee or warranty the products named, and references to them in this publication does not signify our approval to the exclusion of other products of suitable composition. Use pesticides safely. Read and follow directions on the manufacturer's label.

The Institute of Food and Agricultural Sciences (IFAS) is an Equal Opportunity Institution authorized to provide research, educational information and other services only to individuals and institutions that function with non-discrimination with respect to race, creed, color, religion, age, disability, sex, sexual orientation, marital status, national origin, political opinions or affiliations. U.S. Department of Agriculture, Cooperative Extension Service, University of Florida, IFAS, Florida A. \& M. University Cooperative Extension Program, and Boards of County Commissioners Cooperating. Larry Arrington, Dean 
category for which the applications are made. A commercial applicator is usually a contract applicator. The commercial applicator fee for a four-year license is $\$ 160$.

\section{Examinations}

Persons must successfully complete two examinations before they can apply to the Department for a license. These examinations are a Core examination and a Forestry Pest Control category examination. The Core examination may be taken at any University of Florida IFAS County Extension Office. The Forestry Pest Control examination may be taken at a pUniversity of Florida IFAS County Extension Office that offers category examinations. No special qualifications must be met to take the examination. There is no fee to take the examinations.

\section{Study materials}

Manuals and study materials for Core and Forestry Pest Control applicators who will be taking exams may be obtained from the UF/IFAS Extension Bookstore by calling 1-800-226-1764 or on-line at http://www.ifasbooks.ufl.edu/merchant2/. The content of the Core exam is based upon the manual, Applying Pesticides Correctly (Figure 1). The content of the Forestry Pest Control exam is based upon the manual, placePest and Pesticide

Management on Southern Forests (Figure 2). Sample labels may be obtained from suppliers of pesticide products.

\section{Recertification}

Applicators must recertify every four years. To recertify, applicators may take the examinations again or attend training and obtain 8 continuing education units (CEUs) approved for the Forestry Pest Control category and 4 CEUs approved for the Core category. Core CEUs cant be used to meet the required Forestry Pest Control CEUs. No substitutions of other types of CEUs are allowed. Opportunities to earn CEUs may be found at http://www.flaes.org/.

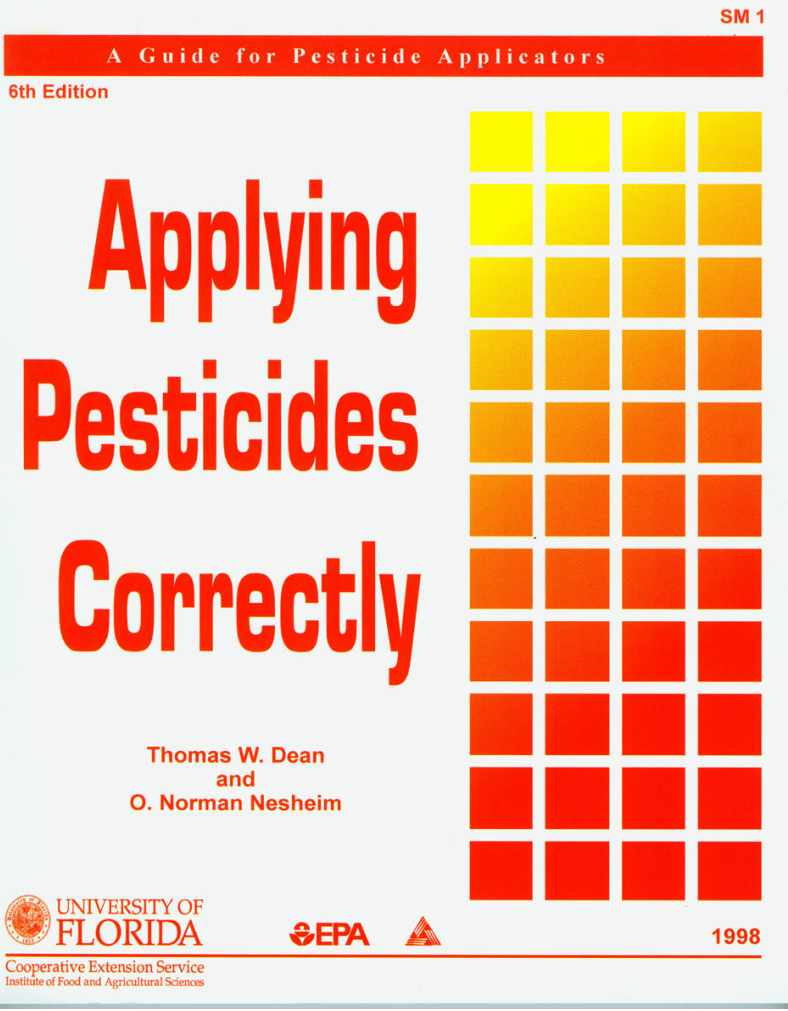

Figure 1. SM 1: Applying Pesticides Correctly

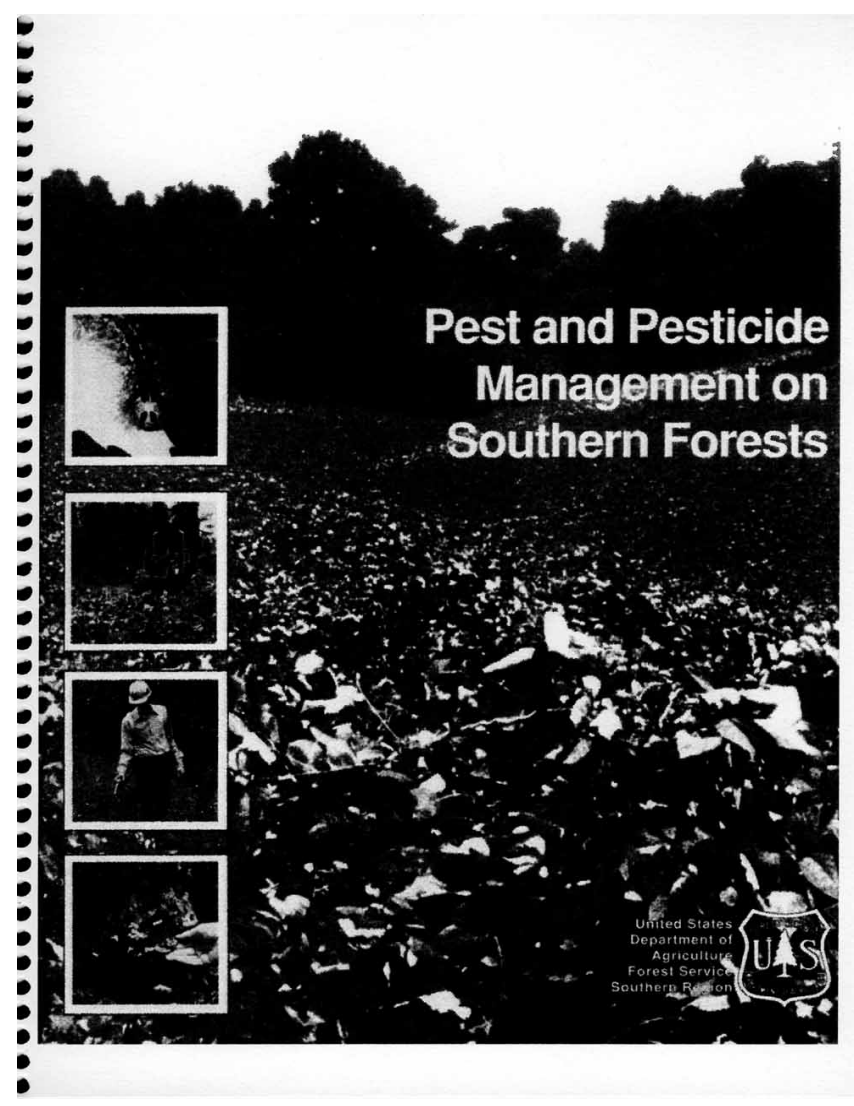

Figure 2. SM 043: Pest and Pesticide Management on Southern Forests 


\section{Restricted use pesticides applied in the Forestry Pest Control category}

Table 1 lists Florida's restricted use pesticides that are applied in the Forestry Pest Control category and the reason for the restricted classification. A complete listing of all restricted use pesticides in Florida may be viewed at:

http://edis.ifas.ufl.edu/PI073.

\section{Additional information}

Fishel, F.M. 2005. Restricted use pesticides.

UF/IFAS EDIS Fact Sheet PI-36,

http://edis.ifas.ufl.edu/PI073.

Florida Department of Agriculture and Consumer Services Bureau of Compliance Monitoring, Pesticide Licensing Section, 3125 Conner Drive, Bldg. 8, L-29, Tallahassee, FL 32399-1650, Phone: 850-488-3314, http://www.flaes.org//complimonitoring/index.html (accessed June 20, 2006).

Florida Statutes, Chapter 487. Florida Pesticide Law.

http://www.leg.state.fl.us/statutes/ index.cfm?App_mode=Display_Statute $\& U R L=C h 04$ 87/ch0487.htm

University of Florida/IFAS Pesticide Information Office, P.O. Box 110710, Bldg. 164, Gainesville, FL 32611-0710, Phone: 352-392-4721, http://pested.ifas.ufl.edu/ (accessed June 20, 2006). 
Table 1. Restricted use pesticides (RUPs) for forest sites in Florida.

\begin{tabular}{||l|l||}
\hline \hline Pesticide common name & Criteria for RUP \\
\hline Atrazine & Ground water contamination potential; worker exposure concerns \\
\hline Azinphos-methyl & $\begin{array}{l}\text { Human inhalation hazard, acute toxicity, hazard to avian, aquatic and } \\
\text { mammalian species }\end{array}$ \\
\hline Carbofuran & Acute inhalation toxicity; avian toxicity (granular) \\
\hline Chloropicrin & Acute inhalation toxicity, hazard to non-target organisms \\
\hline Chlorpyrifos & Avian and aquatic toxicity \\
\hline Diazinon & Avian and aquatic toxicity \\
\hline Dichloropropene & $\begin{array}{l}\text { Probable human carcinogen, oncogenic, acutely toxic by oral and } \\
\text { inhalation routes }\end{array}$ \\
\hline Diflubenzuron & Hazard to wildlife \\
\hline Esfenvalerate & Toxicity to fish and aquatic organisms \\
\hline Methyl bromide & Acute toxicity and accident history \\
\hline Paraquat & Human toxicological data, other hazards - use and accident history \\
\hline Zinc phosphide & $\begin{array}{l}\text { Hazard to non-target organisms, acute oral toxicity, acute inhalation } \\
\text { toxicity }\end{array}$ \\
\hline \hline
\end{tabular}

